Historic, Archive Document

Do not assume content reflects current scientific knowledge, policies, or practices. 



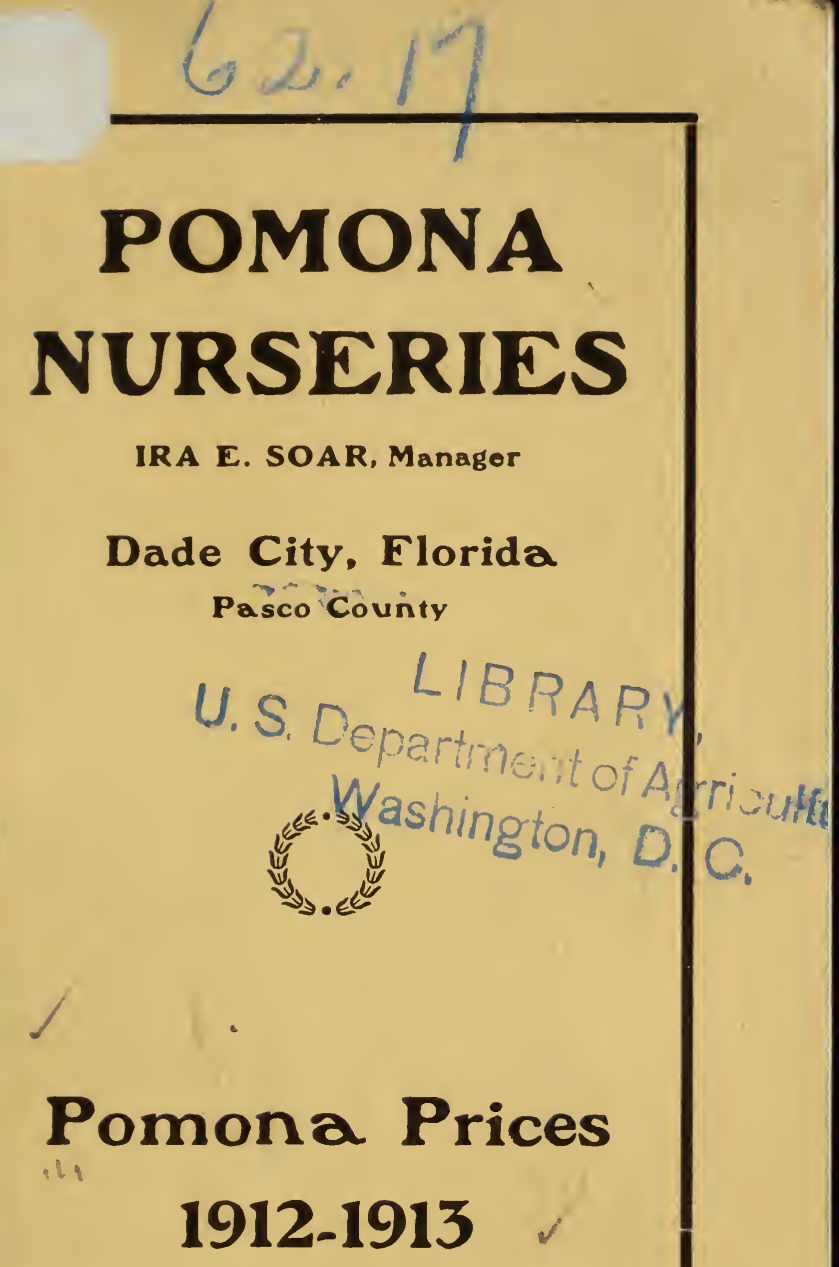




\title{
LIBRARY
}

OF THI

\author{
UNITED STATES \\ DEPARTMENT OF AGRICULTURE
}

Class

\& $1577 B o o k$ 


\section{POMONA NURSERIES}

IRA E. SOAR, Manager

Dade City, Florida

Pasco County

\section{Pomona Prices}

1912-1913

Peach Trees on Plum Roots a Specialty 


\section{Copyright 1912}

By

Pomona Nurseries

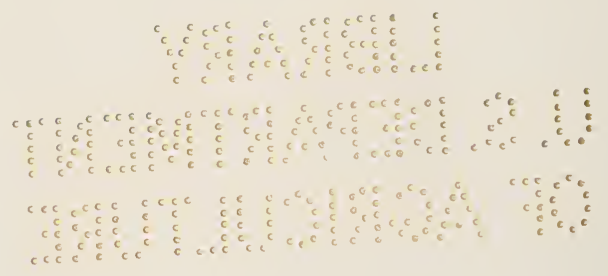

(C) Cl.A329254 


\section{Pomona Nurseries}

\section{Dade City, Florida}

Pomona Nurseries were established in 1882, and are among the oldest in Florida.

We make a specialty of growing Peach and Plum trees on Plum roots.

We originated the method of growing Peach trees on Pasco Plum roots. We were the first to make a success of growing peaches on plum roots, and solved the root-knot problem.

We have been growing Peach trees on plum roots, both in orchard and nursery, for 30 years.

The reputation for peach trees on plum roots has been made and maintained by our stock. 


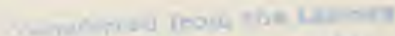

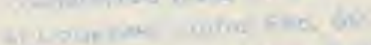

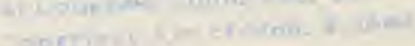




\section{PEACHES.}

The Peach (Prunus Persica) is one of our most valuable fruits and no orchard, whether for home use or commercial purposes, is complete without it. Many people are afraid to plant peaches because they suppose root knot will attack them. However, the day to fear root knot has long since passed. We have solved that problem and for 30 years have been growing and selling peach trees that are immune to root knot. These peach trees are on Pasco Plum roots and as the plum is not attacked by nematodes, they can be grown on old land no matter how badly it is infected with root knot.

\section{HISTORY OF THE PEACH ON PLUM.}

Stephen Soar, founder of Pomona Nurseries, started in the orchard business in 1852 , and has been connected with orchard and nursery work ever since. He noted that the peach was a very short lived tree and set about to remedy this serious defect in an otherwise ideal fruit. Several stocks were tried for propagating trees, but all were finally discarded except the Pasco Plum. In 1882, trees on this plum were tried out along side of peach trees on peach roots. The trees on peach roots nearly all died, while those on plum did well. In every trial the plum stock was found to be vastly superior to the peach. In orchards connected with our nurseries there are peach and plum trees on Pasco Plum stock that are from 15 to 29 years old, and most of them are still thrifty and producing good fruit.

After 30 years' experience growing peaches in South Florida, we cannot recommend peach trees on peach roots. There may be some places where nematodes do not occur that trees will do all right on peach roots, but wherever root knot occurs or is likely to occur, they should be planted only on Pasco Plum.

Some people have tried the Marianna and other inferior plums as a stock on which to grow peaches and plums, and, because the Marianna stunts the growth of the peach, they think the Pasco plum will do likewise, but such is not the case. Our trees have a reputation of 30 years' standing, so to be sure of good trees do not accept anything "just as good" but order Pomona Grown Trees on Pasco Plum roots.

Quicker returns are realized on peaches than on most other fruit crops. They come into good bearing in two or three years, yield heavily and bring remunerative prices. The expense of growing is 
small compared with some other fruits; the first cost of the trees is low, and returns are realized without as many years of care as is necessary with other orchards.

The care of the trees is not difficult. Land should be plowed early in the fall before planting is done. Trees can be set from Dec. 1st to Feb. 1st, although better results are usually obtained when planting is done before Jan. 1st. In planting cut the tree back almost to a straight stick, prune the roots so as to have them smooth and fresh-cut when set; place tree in the hole about the same depth as it came from the nursery and press damp soil well around the roots. After the tree is set make a mulch of loose earth on the surface to hold the moisture.

Fertilizing should not be done at time of planting, but in March or April, and again in June. Cultivate well the first year.

Crops can be grown to advantage in the orchard, especially while the trees are small. The cultivation and fertilizer given the crops will force the trees to make a good growth. The ordinary truck crops, and cotton, corn, cowpeas, velvet beans, beggar weed, peanuts, etc., can be grown to advantage, but it is best to avoid small grains, especially oats. The leguminous crops-velvet beans, cowpeas, etc.are especially valuable, as they put cash in your pocket by gathering a great deal of valuable nitrogen and saving on the fertilizer bill.

Pruning is very important. The trees should be pruned back almost to a straight stick when set. The first and second year after planting they should be cut back to a close head, and in the commercial orchard should always be kept headed in sufficiently that no fruit ladder will be needed. After the third winter the pruning should be done in the summer, immediately after the fruit is off. This gives ample time for another bearing top to form before winter. Whenever a tree begins to turn yellow it should be cut back severely.

Cultivation. After the first year the trees are cultivated until June and then seeded to grass or beggar weed if no other crop occupies the land. In some cases a narrow strip along the rows is cultivated throughout the season.

The peach borer, Sannina exitiosa, can be easily located by the gum which exudes near the ground. It is easy to remove this intruder with a knife or wire. 
We will be glad to answer any questions relating to spraying, or Myriangium duriaei and Sphaerostilbe coccophila, the fungi of most economic importance to the peach.

PEACH TREES ON PASCO PLUM ROOTS.

$\begin{array}{lrrr} & \text { Each } & 10 & 1,000 \\ 1 \text { year, small size, } 2 \text { to } 3 \mathrm{ft} \ldots . & \$ 0.15 & \$ 1.30 & \$ 90.00 \\ 1 \text { year, medium size, } 3 \text { to } 4 \mathrm{ft} . & .20 & 1.75 & 120.00 \\ 1 \text { year, standard size, } 4 \text { to } 6 \mathrm{ft} . & .25 & 2.00 & 150.00 \\ 1 \text { year, large size, } 6 \text { to } 8 \mathrm{ft} . \ldots & .30 & 2.50 & 170.00\end{array}$
100 at 1,000 rates.

Angel. Large size; flesh white, rich, juicy; subacid without bitter noyau. An excellent canning fruit and good shipper. Ripens June 20th to July 5th. A very vigorous grower and prolific bearer.

Bidwell's Early. Large size, roundish with sharp point; fruit fine grained, white, juicy; firm with slight noyau flavor. Fine shipper. Cling. Ripens May 1 st to 20 th.

Bidwell's Late. Very similar to Bidwell's Early but larger, better quality and with less noyau. May 20 th to June 10 th.

Golden Cling. A very large, yellow cling of good quality. Ripens late July to early August.

Hall's Yellow. A seedling of Angel. Good size, red cheek; flesh yellow with red at seed; quality good with sub-acid flavor. A splendid fruit for canning. A good shipper. Ripens June 20 th to July 5 th.

Howard. A peach resembling the Jewel but more highly colored and a little later.

Hudson. A peach resembling the Waldo, somewhat. Color more red, and quality excellent. Ripens in June.

Jewel. The earliest and most profitable market peach grown in Middle and South Florida. It blooms later than Bidwell's Early and Peen-to, and ripens earlier. Fruit medium to large, highly colored, roundish, oblong, pointed; flesh white and very sweet, juicy, melting, with delicious flavor. Free stone and good bearer. Tree vigorous and healthy. Ripens with us April 26th to May 20th, or about 12 to 14 days ahead of Waldo. We have often been the first growers in the United States to ship peaches, and in every instance the shipment was made up of Jewels. This peach comes in two to three weeks before Georgia peaches are ripe, and so has no competition in Northern markets.

Maggie. Closely resembles Bidwell's Early but 
more highly colored and later. Ripens with the Peen-to and later.

Millen's Favorite. An excellent yellow peach, closely resembles the Elberta, but has smaller seed. Yellow, and a free stone.

Mottsfree. A free stone Peen-to ripening later than the Peen-to. Color is not good, but flavor is excellent.

Pallas. Medium size, roundish; quality excellent. Free. Ripens with us in August.

Peen-to. An old and well-known peach. Shaped like a flat turnip, both ends bein's depressed. Quality good with slight noyau flavor. Not recommended as a commercial peach. Ripens May 10th to 25th.

Rival. A large yellow peach. Quality good. Ripens late July to early August.

Waldo. A heavy annual bearer. Fruit medium size with deep red cheek; flesh white, sweet, melting and delicious. Tree a strong grower. Ripens with us May 20th to June 5th.

\section{CITRUS.}

Oranges. (Citrus aurantium.) The Sweet Orange is one of the most popular sub-tropical fruits. It not only deserves a place in every home orchard where citrus trees can be grown, but its culture as a commercial enterprise is very remunerative.

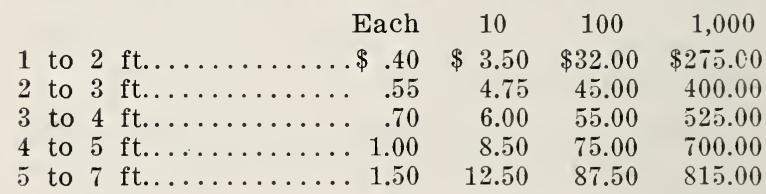

Centennial. Early, but holds quality well. On rough lemon stock.

Majorca. Tree thornless, and a good bearer. Fruit almost seedless, and of good quality. Midseason to late. On rough lemon stock.

Parson Brown. A well known and very popular variety of excellent quality. Season very early. On rough lemon stock.

Pineapple. A very popular variety. Heavy plantings of this kind are being made. Medium to rather late. Rough lemon stock.

Tardiff. (Hart's Late.) A very late variety of excellent quality. Ripens March to July. On rough lemon stock.

Kumquats. (Citrus japonica.) A dwarf orange 
tree, bearing small fruit. On rough lemon and trifoliata stock. $50 \mathrm{c}$ each.

\section{GRAPEFRUIT.}

Pomelo, or Grapefruit. (Citrus pomelanus.) Owing to its high market price and excellent quality, this fruit is very popular with both grower and consumer. Although large plantings have been made, the supply has not kept pace with the rapidly increasing demand. As our supply is limited all orders should be placed early.

\begin{tabular}{rrrrrr} 
& & Each & 10 & 100 & \multicolumn{1}{c}{1,000} \\
1 to $2 \mathrm{ft} . \ldots \ldots \ldots \ldots \ldots$ & .65 & $\$ 5.50$ & $\$ 50.00$ & $\$$ & 450.00 \\
2 to $3 \mathrm{ft} . \ldots \ldots \ldots \ldots$ & .75 & 6.50 & 60.00 & 500.00 \\
3 to $4 \mathrm{ft} \ldots \ldots \ldots \ldots$ & 1.00 & 8.50 & 75.00 & 625.00 \\
4 to $5 \mathrm{ft} \ldots \ldots \ldots \ldots$ & 1.25 & 10.50 & 90.00 & 800.00 \\
5 to $7 \mathrm{ft} \ldots \ldots \ldots \ldots$ & 1.50 & 12.50 & 110.00 & $1,000.00$
\end{tabular}

Ellen. Large size with thin skin. Rough lemon, with a very few on grapefruit.

Marsh Seedless. Medium size and usually evenly distributed over the tree. Few seeds, quality good. Rough lemon with a few on grapefruit stock. Ripens late.

Pernambuco. Large size and of excellent quality. Prolific grower and good bearer. Ripens late. On rough lemon stock.

\section{PECANS.}

Pecans. (Hicoria pecan.) The pecan is rapidy growing in popular favor. The high prices paid for the large, thin shelled varieties make pecan growing very profitable. The best results can be expected on the damper vegetable lands; however, good success may be obtained on any heavy soil. Pecan trees are excellent for shade, attaining great size with symmetrical top, wide-spreading branches, and stately appearance. It is well to plant a few of these trees even if your land is not adapted to growing them on a commercial scale.

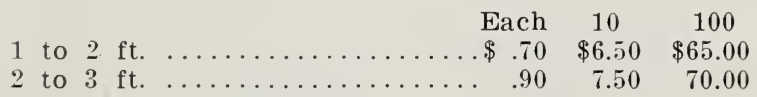

Place your order early, as our supply is limited.

Curtis. Medium size; thin shell, very thin partitions; meat full and of fine quality. A heavy bearer.

Stuart. A large nut, somewhat short, ovoid, with medium thin shell. A very popular variety.

Van Deman. A large oblong nut, with thin shell 
and soft partitions; quality very good; tree strong grower and early, prolific bearer.

We advise planting the budded or grafted varieties, but have a few choice seedlings. 25c each; $\$ 2.10$ per $10 ; \$ 18.00$ per 100 .

\section{PLUMS (Prunus).}

We are not quoting a large number of kinds of plums this year. After testing out a great many varieties we have found it necessary to discard most of them. We do not wish to quote anything that is not adapted to our conditions. All our trees are on Pasco Plum roots and are not to be compared with stock on Marianna or peach roots. Our trees are much stronger growers.

\begin{tabular}{|c|c|c|}
\hline & $\mathrm{Ea}$ & 10 \\
\hline $\mathrm{f}$ & & $\$ 1.50$ \\
\hline & & 2. \\
\hline Ne & .3 & 2.50 \\
\hline lor & .35 & 3.00 \\
\hline
\end{tabular}

Excelsior. A strong grower and sure bearer. Size medium, about $2 \frac{1}{2}$ inches in diameter; nearly round, reddish-purple; good quality, sweet, with slight acid about the seed. Ripens early in June.

Kelsey. Very large, 2 to 3 inches in diameter; covered with heavy bloom; fine quality, sweet and juicy. Color greenish yellow on rich land, deep red on thin, sandy land. A heavy bearer, but not a sure crop. Ripens early in July.

\section{PEARS (Pyrus communis.)}

The blight is not difficult to overcome if varieties of oriental origin are planted on well-drained soils that are inclined to be sandy. By planting on the thinner grades of land, controlling the growth, and correct pruning, blight may be controlled.

\begin{tabular}{|c|c|c|c|}
\hline & Each & 10 & 100 \\
\hline ft., sm & $\$ .20$ & $\$ 1.50$ & $\$ 12$. \\
\hline to $4 \mathrm{ft}$., $\mathrm{me}$ & .25 & 2.00 & 16 \\
\hline to $6 \mathrm{ft}$., sta & .30 & 2.50 & 20. \\
\hline ft. up, larg & .35 & 3.00 & 25. \\
\hline
\end{tabular}

LeConte. Large, pear-shape; flesh sweet, juicy and of excellent quality. Like most other pears this fruit should be gathered before it is mature and ripened in a dark room. Ripens late June to early July.

Kieffer. Very large; yellow with red cheek. A prolific bearer; fruit usually has to be thinned. Matures in September.

Magnolia. Fruit a russet brown. Later than Kieffer and an excellent keeper. 


\section{JAPAN PERSIMMONS (Diospyros Kaki.)}

This splendid fruit should be in every home orchard. It is easy to grow, being a prolific bearer, with few insect enemies. Its increasing popularity in the market makes it worth considering as a commercial proposition.

Each $10 \quad 100$

2 to 3 ft., small size......... $\$ .20 \quad \$ 1.50 \quad \$ 13.00$

3 to $4 \mathrm{ft}$., medium size........ .25 $2.00 \quad 17.00$

Hyachiya. Large, oblong, pointed; very red and showy. Flesh yellow with few seeds, astringent; very delicious when fully ripe.

Hyakume. Large size, flattened at each end; flesh dark, not astringent. A good bearer.

Tane-Nashi. Very prolific. The most desirable for market. Very large, pointed and conical. A handsome fruit; yellow flesh; quality unsurpassed.

\section{MULBERRIES (Morus).}

Very good shade trees, producing abundant crops of fruit excellent for home consumption, feeding poultry and swine and tolling birds away from more valuable fruit.

$$
\text { Each } 10
$$

2 to 3 ft., small size......... $.15 \$ 1.20$

3 to 4 ft., medium size......... .20 1.50

4 to $6 \mathrm{ft}$., standard side........ $.25 \quad 2.00$

Downing. Makes a very symmetrical shade tree. Berries rather small, sub-acid; splendid for eating out of hand.

Hicks. A strong grower but not as handsome a tree as Downing. Produces abundant crops of large berries, sweet and rather insipid.

\section{POMEGRANATES (Punica granatum.)}

The pomegranate is a very attractive tree, bearing brilliant scarlet flowers and fruit noted for its crispness and delicate sprightliness of flavor. We quote the Purple Seeded, one of the best varieties.

$$
\text { Each } 10
$$

2 to $3 \mathrm{ft}$, small size........\$ .25 $\$ 2.00$

3 to 4 ft., medium size....... . .30 2.50

\section{FIGS (Ficus carica.)}

The fig is one of the most delicious of all fruits and should be more generally grown. It is sometimes attacked by nametodes; however, heavy mulching or planting close up to a building will shade the ground and be beneficial. As the root system is close to the surface, deep cultivation should never occur. 
Each $10 \quad 100$

1 to 2 ft. $\ldots \ldots \ldots \ldots \ldots \ldots \ldots \ldots .15 \quad \$ 1.25 \quad \$ 10.00$

Celestial. Called Sugar F'ig. Very rich and sweet. Fruit small, brownish yellow, and of splendid quality. A very desirable variety. Hardy, and one of the most prolific kinds.

\section{GRAPES (Vitis).}

The growth of our towns and cities has opened up home markets in Florida and adjoining states that justify much more extensive plantings of grapes than we have witnessed in the rast. The Muscadine group is at home here, and there are several varieties of bunch grapes that do well. Bunch grapes should be trained to stakes or trellis. The fruit is produced on new wood, and, consequently, it is necessary to prune back closely each year.

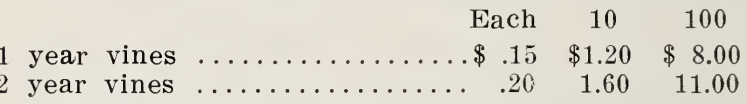

Agawam. Rather large; maroon color; flesh pulpy with rich juice of striking aromatic flavor.

Delaware. Berries small size, reddish pink; sweet, juicy and of excellent quality.

Ives. Berries medium size, black; pulpy and good quality. A strong grower and good shipper.

Niagara. Bunches very large; berries large, white, sweet, with excellent flavor. Strong grower and very productive. Very popular in Florida markets.

Scuppernorny. A well-known variety of the Muscadine group. Bunch small; fruit large, pulpy and filled with sweet juice; quality excellent; color bronze, A strong grower. Grown on arbor and not pruned as the bunch grapes. Splendid for home consumption, but never planted extensively.

\section{EVERGREENS, HEDGE PLANTS AND SHADE TREES.}

Arborvitae. (Thuya, or Biota.) This genus contains some of the choicest evergreen plants for specimens, hedges, etc.

T. Orientalis. Chinese Arborvitae. A well known specimen and hedge plant. Growth upright, pyramidal and open. Nice plants, $15 \mathrm{c}$ and $25 \mathrm{c}$.

T. aurea nana. A very handsome dwarf Arborvitae; habit compact; a general favorite. Very fine plants, $35 \mathrm{c}$ to $\$ 1.25$.

T. Rosedale Hybred. A dense growing, conical 
variety. In winter its dark green growth often turns to bronze at the tips. Fine plants, 35c to $\$ 1.25$.

Juniperus Virginiana. Red Cedar. A beautiful tree of dark green color, attaining large size. 25c each; $\$ 2.00$ per 10 .

Ligustrum ovalifolium. Califo:nia Privet. An old, well-known hedge plant; deciduous, foliage green. A strong grower. $\$ 5.00, \$ 6.00$ and $\$ 7.00$ per 100 .

Cinnamonum camphora. Camphor An ornamental tree for specimens and hedges. A rigorous tree, attaining large size if not pruned back. The camphor gum of commerce is obtained from this tree. $15 \mathrm{c}$ and $25 \mathrm{c}$ each.

Liquidambar styraciflua. Sweet Gum. This tree thrives on both wet and dry lands. Very thrifty; ornamental, has leaves resembling maple. Strong trees, $\$ 2.00$ to $\$ 10.00$ per 10 .

Melia Azedarach umbraculiformis. Umbrella China Tree. An umbrella-shaped, deciduous tree, making a dense shade. Needs rich soil. 2 to 3 feet, 25 c each; $\$ 2.00$ per 10 .

Quercus larifolia, and phellos. "Water Oak." Not the true Water Oak (Q. nigra aquataca) but Laurel and Willow Oak. They are much better for street planting than the true Water Oak. $\$ 2.00$ to $\$ 5.00$ per 10 . Special prices on large quantities.

Q. suber. The Cork Oak. A splendid shade and ornamental tree producing the cork of commerce. Strong tre $€ \mathrm{~s}, 50 \mathrm{c}$ each; $\$ 4.50$ per 10 ; larger size, $75 \mathrm{c}$ each; $\$ 7.00$ per 10 .

\section{CYCADS AND PALMS.}

Cycas revoluta. Sago Palm. A beautiful plant for specimen planting. Has dark green leaves. 25c, $50 \mathrm{c}$ and $75 \mathrm{c}$ each.

C. Zamia integrifolia. Comptie. A cycad indigenous to Florida. Small plant; seldom more than two feet in height, with dark green foliage. Excellent as specimen and border plants. Strong plants, $25 \mathrm{c}$ to $50 \mathrm{c}$ each; $\$ 2.00$ to $\$ 4.00$ per 10 .

Phoenix dactylifera. The Date of commerce. Adapted to open planting in Florida. A splendid ornamental tree, with light green foliage and upright growth. Small seedlinos, 15c each; $\$ 1.00$ per 10 ; nice plants $50 \mathrm{c}$ to $\$ 1.00$ each. Very large plants $\$ 2.00$ to $\$ 5.00$ each.

Rhapidophyllum hystrix. Needle Palm. A native of Florida but rather rare. A very handsome plant with deep green leaves, and spines at the base. 
Used as specimens and for borders. Fine plants, $50 \mathrm{c}$ to $75 \mathrm{c}$ each; $\$ 4.00$ to $\$ 6.00$ per 10 .

Sabal Adansonii. (S. Glabra.) Dwarf Palmetto. Closely resembles S. Palmetto but stalky and never grows tall. Fine plants, 35c, 50c, 75c, $\$ 1.00, \$ 1.50$ and $\$ 2.00$ each.

S. Palmetto. The common Cabbage Palmetto. A very tall tree with immense bunch of leaves at the crown. Suitable for specimen and street planting in Florida and elsewhere in the South near the Gulf and Atlantic coasts.

Strong plants: Each, 15c; $10, \$ 1.25 ; 100, \$ 10.00$

Large plants: Each, $25 \mathrm{c}$ to $50 \mathrm{c} ; 10, \$ 1.75$ to $\$ 3.50$; $100, \$ 12.00$ to $\$ 20.00$.

Very large plants: $75 \mathrm{c}$ to $\$ 1.75 ; 10, \$ 5.00$ to $\$ 10.00$.

Extra large plants: $\$ 2.00$ to $\$ 5.00$.

\section{CANNAS.}

Cannas thrive in a rich, damp soil. Their brilliant, gorgeous colored flowers make them plants of surpassing beauty.

Austria. Gorgeous, orchid-like flowers; color golden-yellow, with faint blotches of orange-scarlet in center. Immense size, very prolific grower. $15 \mathrm{c}$ each; $\$ 1.00$ per 10 .

Italia. A very popular variety. Has immense orchid-like flowers; golden-yellow with brilliant orange-scarlet blotches. A most desirable kind. $15 \mathrm{c}$ each; $\$ 1.00$ per 10 .

\section{LILIES.}

Amaryllis equestre. Very beautiful; flowers medium size and scarlet. Flowering bulbs, $15 \mathrm{c}$ each; $\$ 1.00$ per 10 .

Crinum fimbriatulum. Milk and Wine Lily. A vigorous grower in most all soils. Flowers large, striped carmine and white. Flowering bulbs, $15 \mathrm{c}$ each; $\$ 1.00$ per 10 .

Crinum Kirkii. Ten to fifteen flowers are often borne at the top of a purple stem. Flowers of good size, white with carmine-purple stripe on under side of petals. Often blooms several times during the season. Blooming bulbs, $25 \mathrm{c}$ to $50 \mathrm{c}$ each; $\$ 2.00$ to $\$ 3.00$ per 10 .

Hymenocallis carribbaeum. The Spider Lily. A pure white lily, and a prolific bloomer. Nice size, 10c each; $75 \mathrm{c}$ per 10; large size, $15 \mathrm{c}$ to $25 \mathrm{c}$ each; $\$ 1.25$ to $\$ 2.00$ per 10 . 


\section{AGAVES, CACTI AND YUCCAS.}

Agave Americana variegata. The variegated Century Plant. Beautiful leaves with green and silvercream stripes. $25 \mathrm{c}$ to $35 \mathrm{c}$ each.

A. decipens. The green leaved Century Plant. A flower stalk fifteen to eighteen feet high makes this plant greatly admired. $15 \mathrm{c}, 25 \mathrm{c}$ and $50 \mathrm{c}$ each.

Yucca aloifolia. Spanish Bayonet, or Spanish Dagger. A very ornamental plant with needle-pointed leaves. Flowers pure white, waxy and borne on short spike. Grows ten to eighteen feet high. 15c, $25 \mathrm{c}, 50 \mathrm{c}$ and $\$ 1.00$ each.

Y. filamentosa. Bear Grass. A low growing species. Flowers pure white, waxy; tall graceful spike. Large plants, $25 \mathrm{c}$ to $50 \mathrm{c}$ each.

Epiphyllum truncatum. Crab-claw Cactus, or Christmas Cactus. An excellent cactus for hangingbaskets. Pink flowers of rare beauty appear in midwinter. Nice plants, $15 \mathrm{c}$ and $25 \mathrm{c}$; grafted plants, $50 \mathrm{c}$ and $75 \mathrm{c}$ each.

Pereskia aculeata. Barbados Gooseberry. A strong growing cactus vine. $10 \mathrm{c}$ each; $80 \mathrm{c}$ per 10.

\section{GRASSES.}

The following species are valuable for ornamental and forage purposes.

Arundo donax variegata. A thrifty reed, often reaches a height of ten to fifteen feet. Variegated while shoots are young. 25c each; $\$ 1.50$ per 10 .

Gynerium Cortaderia Selloana. Silver Pampas Grass. Grows in enormous clumps, and sends up feathery white plumes. 35c each; $\$ 1.50$ per 10 .

Pink Pampas Grass. Has pink plumes. 35c each; $\$ 1.50$ per 10 .

Panicum maximum. Guinea Grass. A vigorous growing grass for forage purposes. Grows best in heavy rich well drained soil. $\$ 2.00$ for 100 plants.

Panicum molle. Para Grass. A forage grass that grows on both wet and dry land. Grown from the stalks. $\$ 1.00$ per 100 stalks.

Stenotaphrum glabrum. St. Augustine Grass. An excellent grass for the lawn; also good for grazing. Grows well under shade of trees and shrubs, and remains green when most other grasses have turned brown. $\$ 1.00$ per bushel.

\section{SHRUBS AND FLOWERING PLANTS.}

Achania malvaviscus. A thrifty grower in rich land. Flowers are deep scarlet. Nice plants, $15 \mathrm{c}$ each; $\$ 1.00$ per 10 . 
Brugmansea Akorca. Angel's Trumpet. A thrifty grower; kills to the ground when ice forms, but soon starts up again. F'lowers immense, white and trumpet-like. Nice plants, $15 \mathrm{c}$ and $25 \mathrm{c}$ each.

Gardenia florida. Cape Jessamine. A beautiful llant with dark green foliage. Flowers white, with decided fragrance. $15 \mathrm{c}$ and $25 \mathrm{c}$ each.

Hibiszus Syriacus. Althea or Rose of Sharon. We offer the following shades: White, Deep Purplepink, Violet-purple and Purple-Magnetio with crimson center, 2 to $3 \mathrm{ft}$., $25 \mathrm{c}$ each; 3 to $4 \mathrm{ft}$., $40 \mathrm{c}$ each.

Lagerstroemia indica. Crape Myrtle. A hardy Indian shrub of rare beauty. Bears great masses of deep tinted flowers; a very persistent bloomer. Excellent for specimens, masses and hedges. We carry two shades: Light Pink and Purple. Large, stronğ plants, 20c each; $\$ 1.00$ per $10, \$ 12.00$ per 100 . Very large plants, 50c each, $\$ 4.00$ per $10 ; \$ 35 . C 0$ per 100 .

Nerium Oleander. Oleander. We offer two colors: White and Pink. Nice plants, 25c each; $\$ 2.00$ per 10 .

Pyrus Japonicus. Flowering or Japanese Quince. A very hardy shrub. Brilliant scarlet flowers are borne in winter when the plant is devoid of leaves. $15 \mathrm{c}$ and $25 \mathrm{c}$ each.

Spiraea Reevesii. Bridal Wreath. Well known, hardy shrub; producing a mass of white flowers in the spring. Fine large plants, $25 \mathrm{c}$ each; $\$ 2.00$ per 10 .

Violets-California. A very strong grower and prolific bloomer. 10c per bunch.

\section{ROSES.}

The roses quoted below have been carefully selected as best suited to our conditions. Most all are strong-growing kinds and those which are not so vigorous have a quality of flower that especially commends them. The running varieties may be pruned back to bush form, if desired. Most roses are not pruned sufficiently; flowers are borne on new wood, and pruning induces the formation of new, thrifty growth. Fertilize only after plants are well established. Well rotted compost and bone meal are good. If ashes are used do not mix with compost or apply at the same time. December and January plantings usually give the best results, although by pruning, watering and shading, plants may be set at any time.

Strong field grown stock, 25c and $35 \mathrm{c}$ each; $\$ 2.00$ and $\$ 3.00$ per 10 . 


\section{Bush Varieties:}

American Beauty. Hybrid Tea. A very popular kind. Flowers very large, brilliant red with rich carmine-crimson shade.

Bride. Tea. A strong grower and general favorite. Persistent bloomer; flowers beautiful white with slight tint of pink at some seasons.

Clothilde Soupert. Hybrid Polyantha. Flowers medium size, white with slight shade of pink in center; fragrance very pronounced, especially when wet with dew.

Dutchess de Brabant. Tea. Very popular. Strong grower and constant bloomer. One of the best. A striking shell-pink; beautiful in bud, or open.

Louis Phillipe. Bengal. A very hardy variety. Flowers large, fiery red with center shading slightly into pink.

Mad. Jos. Swartz. Tea. Much like its parent, Dutchess de Brabant, in growth. F'lowers of good size, sweet; color pearly white with delicate shading of shell-pink along the edge of petals, sometimes this is very distinct, especially in the center.

Safrano. Tea. An especially vigorous grower. Flowers of medium size, saffron to buff-yellow; decidedly a bud rose.

\section{"Climbing Varieties:}

Clothilde Soupert. Climbing Tea. Closely resembling Clothilde Soupert mentioned above.

Crimson Rambler. Climbing Polyantha. A wellknown variety. Produces great clusters of small crimson flowers. Blooming period lasts four to six weeks.

Marechal Niel. Climbinz Noisette. The most popular variety we carry. Strong and profuse bloomer. Rich golden yellow color, and sweet scented.

Reine Marie Henriette. Climbing Tea. A rampant climber. Flowers large and beautifully shaped; cherry red without undesirable tints.

\section{VINES AND CLIMBING SHRUBS.}

Allamanda Williamsii. Allamanda. Thrifty climbing shrub with golden flowers about three inches across. 25c each; $\$ 3.00$ per 10 .

Bignonia radicáns. Trumpet creeper. A strong growing deciduous vine with compound leaves; flowers red and borne in clusters. 20c each; $\$ 1.50$ pe 10. 
Clerodendron delicatum. A very stronz grower; flowers scarlet with green calyx. $25 \mathrm{c}$ and $35 \mathrm{c}$ each.

Gelsemium sempervirens. Yellow Jessamine. A strong growing vine with dark green foliage; flowers deep yellow and bell-shaped. Blooms in winter and spring. $15 \mathrm{c}$ each, $\$ 1.00$ per 10 .

Lonicera Halleana. Honeysuckle. A very desirable kind. Strong grower, persistent bloomer; flowers white and slowly changing to cream-yellow. Nice plants, $15 \mathrm{c}$ each; $\$ 1.00$ per 10 . Large plants, 25c each; $\$ 1.50$ per 10 .

Wistaria Sinensis. Wisteria. A well-known variety. Excellent for trellis or by close pruning can be made to take on bush form. Bears great clusters of purple flowers before leaves appear. Strong plants, 25c each; $\$ 2.00$ per 10 . Large plants, 35c each; $\$ 3.00$ per 10 .

\section{FERNS.}

Ferns are among the most beautiful decorative plants and no collection of house plants is complete without them. They should be planted in rich soil and watered regularly.

Nephrolepis exaltata. Sword Fern. A kind much used for baskets, pots and pedestals. 10c each; $80 \mathrm{c}$ per 10 .

N. exaltata bostoniensis. Boston Fern. A sport from $N$. exaltata that is now widely taking its place. Very similar in appearance with fronds much more numerous. $10 \mathrm{c}$ to $50 \mathrm{c}$ each. 


\section{CANNING MACHINERY NO. B.}

One canner, 2 lifting hooks, 1 tray, 1 charcoal furnace, 1 soldering copper and one book of instructions. Capacity 300 to 1,000 cans per day. Priee, $\$ 15.00$. Shipping weight 60 pounds.

Cover', 35c.

\section{PORTABLE CANNING MACHINE NO. 1.}

One canner, 3 trays, 1 globe valve, 1 capping steel, 2 tipping coppers, 1 charcoal furnace, book of instructions and 1 pair of can tongs. Capacity 400 to 1500 cans per day. Shipping weight 90 pounds. Price, $\$ 25.00$.

\section{CANNING MACHINE NO $1 \mathrm{~S}$.}

No. 1S, with scalding attachment, same implements and capacity as No. 1, with additional blanching basket. Capacity 400 to 1500 cans per day. Shipping weight, 110 pounds. Price, $\$ 30.00$.

\section{CANNING MACHINE NO 2.}

One canner, 6 trays, 4 lifting hooks, 1 pair can tongs, 2 capping steels, 1 charcoal furnace, 1 valve, 1 scalding or blanching basket, 2 tipping coppers and book of instructions. Capacity 700 to 2500 cans per day. Shipping weight 200 pounds. Price, $\$ 50.00$.

\section{CANNING MACHINE NO 3.}

One canner, 15 trays, 10 lifting hooks, 1 pair can tongs, 4 capping steels, 2 charcoal furnaces, 4 tipping coppers, 1 globe valve, 2 blanching baskets and book of instructions. Capacity 700 to 5000 cans per day. Shipping weight 300 pounds. Price, $\$ 100.00$.

\section{CAPPING STEEL.}

Every owner of a canner should have a Capping Steel. They are made especially for sealing the cans and do the work neatly and rapidly. 250 cans per hour can be sealed with two of these steels. Directions come with them. No. B canner is not supplied, No. 1 and $1 \mathrm{~S}$ have one each, while the others have two or more. Price, standard size 2 1-16 inch opening, $\$ 2.00$.

\section{TERMS, PREMIUMS AND SPECIAL OFFERS.}

Terms are cash with order.

Freight will be prepaid when three or more canners go to one address at the same time.

We will give nursery stock to the value of $\$ 1.00$ with each $\$ 15.00$ canner, or, if outfits of higher price are ordered, stock to the amount of $\$ 1.00$ for each 
$\$ 15.00$ of the price. The selection of this stock is to be from peaches, plums, grapes (not Scuppernongs), mulberries, Sabal Palmettoes, cannas, shrubs, riolets, cactii and flowering plants, vines and climbing shrubs. We reserve the right to give any stock we may select, but will be governed by the choice of our patrons as far as possible. When premium plants are sent by mail $10 \mathrm{c}$ should be added for postage. As this offer does not hold after the nursery stock is exhausted, all orders should be placed at an early date.

We will make a present of one $\$ 15.00$ canner to any person sending us a club order for five $\$ 15.00$ outfits, or outfits of higher price totaling $\$ 75.00$ in amount. In the same way we will give any of the above canners with an order totaling five times the price of the premium outfit. With each club order we will also send the nursery stock offered above.

The above terms apply only to counties in Florida in which there is no resident agent for these canners. In writing mention your county, and we will inform you if there is an agent in your territory.

Any person desiring a regular agency for this line of canners should write us for terms. 


\section{TERMS AND CONDITIONS.}

Terms. Cash with order when stock is for immediate shipment. When order is placed before shipping season, 25 per cent. of the amount should accompany it, to insure us reserving the stock, balance due when ordering goods shipped.

Season for Handling. Stock will be ready for shipment December 1st. We advise early setting of all deciduous stock, as much better results are usually obtained by planting in December. Late planted trees do not get as well established before the growing season opens. Citrus trees are usually set from January throughout the spring and summer. Many roses, plants and vines can be set at any time of the year by cutting back, watering and shading, but usually do best if moved between Novembor and March.

Size of Orders. We prefer not to handle any orders amounting to less than $\$ 1.00$.

Shipments. Orders are carefully graded, labeled and packed. Shipments are made on A. C. L. and S. A. L. railways. We are not responsible for stock after turning over to transportation companies. We park so that stock will stand considerable delay in transit; and will start tracers after delayed shipments and do all in our power to insure delivery. Howver, we are not responsible for loss or damage after goois 'eave us; all such claims shouid be inade upon the transportation companies.

Prices. The prices quoted are for trees well packed and delivered f. o. b. Dade City. Purchasers are to bear freight and express charges. 5 trees or plants at 10 rates, 50 at 100 rates, and 500 at 1,000 rates, except where orders are made up of long lists of a few each of many kinds.

We guarantee all stock to be true to name, well packed and shipped according to instructions. Under this guarantee our liability is limited in amount to the original price of stock.

Claims. We use every precaution to prevent mistakes, but, if any should occur, will gladly correct them. All such claims must be made imm зdiately upon receipt of goods.

Mail Shipments. Small plants, trees, vines and shrubs can be sent by mail. Where orders to be shipped amount to less than $\$ 1.00$ add 10 c extra. Plants sent by mail may not be up to size quoted. We reserve the right to refuse orders that we can not conveniently handle in this way. 
Shipping Directions. Please state whether goods are to go by freight, express, or mail, and give shipping point if different from postoffice. Money should be sent by registered letter, bank draft, postoffice money order, or express order.

On Receipt of goods, all trees and plants should be taken from the package and immediately "heeled in" under shade where the soil is moist. If dry upon arrival, place in water for a couple of hours before unpacking. Plant as soon as possible.

\section{DISTANCES FOR PLANTING.}

Feet each way

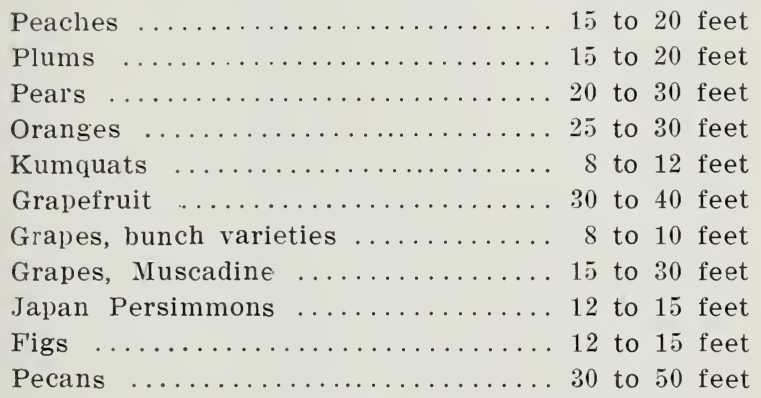

\section{SQUARE FORM-NUMBER OF TREES TO THE ACRE.}

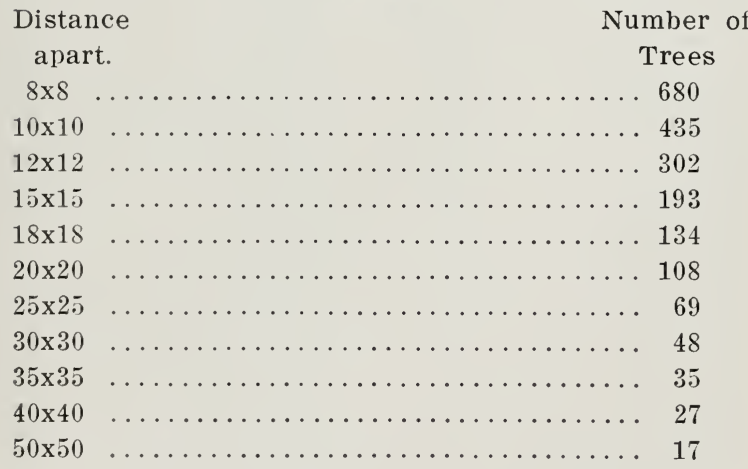




\section{CONTENTS.}

Achania Page

Agaves .............. 15

Allamanda . ....... 17

Althaea

Amaryllis ........... 14

Angel's Trumpet. . 16

Arborvitae . . . . . . . 12

Arundo ............. 15

Barbados Goose-

berry _............. 15

Bear Grass . . . . 15

Bignonia - . . . .

Biota _.............. 12

Boston Fern 18

Brugmansea .

Bridal Wreath _._. 16

Cactus ................ 15

Camphor Tree...... 13

Cannas ............. 14

Canning Outfits ... 18,19

Cape Jessamine _._._. 16

Capping Steel_......._20

Cedar._........... 13

Century Plant.......15

Cinnamonum ........ 13

Citrus _. _ ........ 8, 9

Clerodendron ........ 18

Cortaderia_._....._._. 15

Crab-claw Cactus ....15

Crape Myrtle.......16

Crinum _...

Date Palms... 13

Diospyros ............11

Epiphyllum .......... 15

Evergreens _......12, 13

Ferns . . . . .

Eicus .

Figs _..............11, 12

Gardenia ........... 16

Gelsemium ......... 18

Grape .............. 12

Grapefruit_......... 9

Grasses ............ 15

Guinea Grass.....

Gynerium ............ 15

Hicoria ............ 9

Hibiscus

Honey suckle _...... 18

Hymenocallis . . . . . . 14

Japan Persimmon_.. 11

Japanese Quince_____16

Jessamine ......... 16

Juniperus _............ 13

Kumquat ........ 8,9

Lagerstroemia ..... 16

Lilies ....

Ligustrum ......... 13

\section{Page}

Liquidambar ........ 13

Lonicera............ 18

Melia . . _. _._._._. 13

Milk and Wine Lily_14

Morus _._._._._._._._._11

Mulberries_._._._._._. 11

Muscadine Grape... 12

Needle Palm_.........13

Nephrolepis .......... iu

Nerium _..............16;

Oaks............... 13

Oleander _..._..._._. 16

Orange............ 8, 9

Palmetto............ 14

Palms _......... 13

Pampas Grass..... 15

Panicum _........... 15

Para Grass

Peaches ............ . 5-8

Pears _._._._._. 10

Pecans............. 9

Pereskia _... ........15

Persimmon ......... 11

Phoenix _.............13

Plums _....... 10

Pomegranate ........1]

Pomelo _..._._. . . _._. 9

Premiums ......20, 21

Privet ............... 13

Prunus ........... 10

Punica

Pyrus.... . . . . - 16

Quercus..............13

Quince (Japanese) .... 16 Rhapidophyllum _.13, 14

Rose of Sharon _..._. 16

Roses _............16, 17

Sago Palm ........... 13

Sabal............... 14

Spanish Bayonet _... 15

Spiraea _. _......._. 16

St. Augustine Grass_15

Stenotaphrum .......15

Sweet Gum Tree..... 13

Sweet Orange....... 8

Thuy a . .......... 12

Trumpet Creeper._._. 17

Umbrella China_..... 13

Violets . . . . . 16

Vines _......... 18

Vitis ............. 12

W ater Oaks ........... 13

Wistaria ............. 18

Yellow Jessamine... 18

Yucea

Zamia .............. 


\section{ORDER SHEET}

\section{Pomona Nurseries Dade City, Fla.}

Find enclosed.

$$
\text { (Money Order. Draft, or Cash) }
$$

Ship by (Express, Freight, or Mitil)

Name

Post Office.

R. R.

County

If the stock you order is exhausted, may we substitute with other goods? (Yes, or No.)

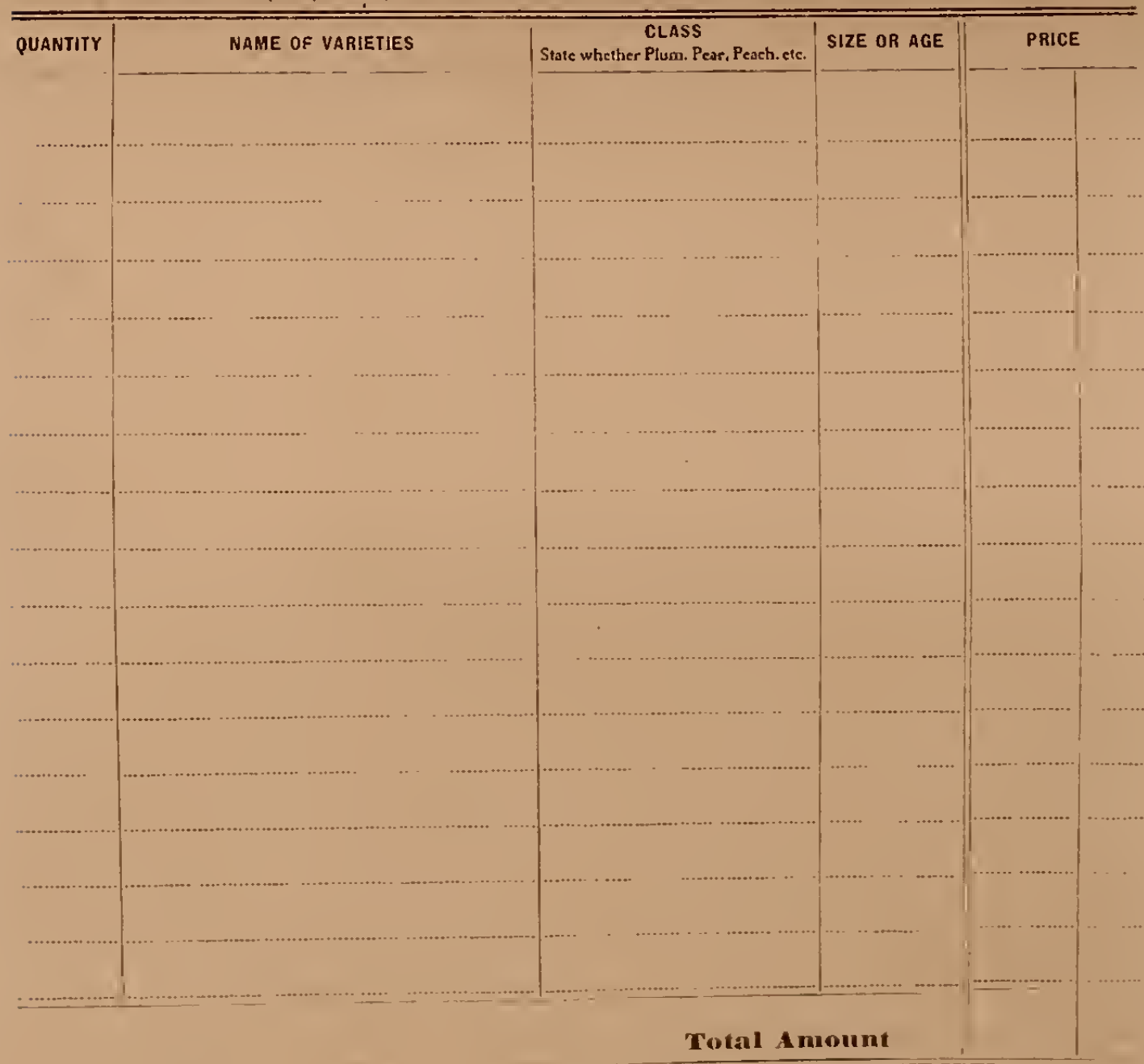




Pepper Publishing \& Printing Co. Gainesville, Floridz 